\title{
The Serological Identity of Sabin's Murine type C Mycoplasma and Mycoplasma pulmonis
}

\author{
By RUTH M. LEMCKE \\ Department of Microbiology, Lister Institute of Preventive Medicine, \\ Chelsea Bridge Road, London, S.W. I \\ AND KATHRYN A. FORSHAW AND R. J. FALLON \\ University Department of Infectious Diseases and Department of Pathology, \\ Ruchill Hospital, Glasgow, N.W.
}

(Accepted for publication 6 June 1969)

SUMMARY

Serological evidence is presented that Sabin's murine type C mycoplasma belongs to the species Mycoplasma pulmonis and not to a separate species, M. histotropicum.

Between 1938 and I94I, several apparently distinct mycoplasmas were isolated from mice by Sabin (1938, I939 $a, b, 194 \mathrm{I})$. These organisms were designated types A, B, C, D and E and assigned to three species, 'Musculomyces neurolyticus' (type A), 'Musculomyces arthrotropicus' (type B) and 'Musculomyces histotropicus' (types C, D, E) (Sabin, I94I). The toxinogenic type A was evidently the same as the organism first isolated by Klieneberger from mice with rolling disease (Findlay, Klieneberger, MacCallum \& Mackenzie, I938; Klieneberger, 1940) and later classified as Mycoplasma neurolyticum (Edward \& Freundt, 1956). However, the relationship of types B, C, D and E to the other recognized rodent mycoplasmas, $M$. pulmonis and $M$. arthritidis (Edward \& Freundt, I956) could not be determined from Sabin's descriptions. In 1963, types $\mathrm{A}$ and $\mathrm{C}$ were recovered from cultures which had been lyophilized in 1943 (Tully \& Ruchman, 1964): type A proved to belong to the species $M$. neurolyticum, while type $\mathrm{C}$ was provisionally designated, on the results of indirect fluorescent antibody tests, as $M$. histotropicus (Tully, 1965), a species distinct from the other rodent mycoplasmas. Since Mycoplasma is a neuter noun, with which the specific epithet must agree, the name of this organism was corrected by Edward \& Freundt (1969) to $M$. histotropicum. More recently, the electrophoretic pattern of the cell proteins of type C (M. histotropicum, PG 40, obtained from Dr D. G. ff. Edward) was found to resemble that of $M$. pulmonis strains (Razin, 1968). We show here that two lines of type $\mathrm{C}$ are antigenically indistinguishable from $M$. pulmonis.

A culture of type $C$, which had undergone 60 passages since recovery from Sabin's lyophilized material, was received from Dr J. G. Tully (National Institutes of Health, Bethesda, Md., U.S.A.) and examined at the Lister Institute in 1964. The culture was cloned by selecting a single colony at each of two successive subcultures, and tested by complement-fixation and gel-diffusion (Lemcke, 1964, 1965) and by an agar growthinhibition technique (Clyde, 1964) against antisera to 17 serologically distinct mycoplasmas (Lemcke, 1964). It reacted only with antisera to two strains of Mycoplasma 
pulmonis, KON from the lung of a rat and M I from the lung of a mouse (Lemcke, I96I). No reaction occurred with antisera to $M$. hominis (strain H34), M. pneumoniae (FH), $M$. salivarium (в 3), $M$. orale, type I (823), $M$. fermentans (G 2), $M$. arthritidis (CAMPo, PG 27), $M$. neurolyticum (KSA), $M$. gallinarum (FOWL), $M$. gallisepticum (T), $M$. laidlawii (type A), $M$. agalactiae (agalactia), $M$. bovigenitalium (PG II), $M$. mycoides var. mycoides (GLADYSDALE), M. mycoides var. capri (pp. goat) or two strains, NAVEL and A 36, not yet accorded species rank.

More recently, antiserum was prepared against the same cloned line of type $\mathrm{C}$, and further complement-fixation, gel-diffusion and growth-inhibition tests were made with this antiserum and antisera to KON and MI. The gel-diffusion antigens were mycoplasma suspensions lysed with the non-ionic detergent Triton X-I00 and not the sonicated suspensions used previously (Lemcke, 1965). The complement-fixation and growth-inhibition tests confirmed the close relation of the three organisms (Table I). In gel-diffusion tests, reactions with homologous antisera tended to be more complex than those with heterologous antisera, but the majority of the antigens was shared by all three strains (Table I).

Table I. Reactions of type C and strains MI and KON of Mycoplasma pulmonis in complement-fixation $(C F)$, growth-inhibition and gel-diffusion tests

Complement-fixation cited as reciprocal of titre, growth-inhibition as width of inhibition zone. For gel-diffusion tests, figures in parentheses indicate number of precipitin lines shared with homologous strain. Homologous reactions in heavy type.

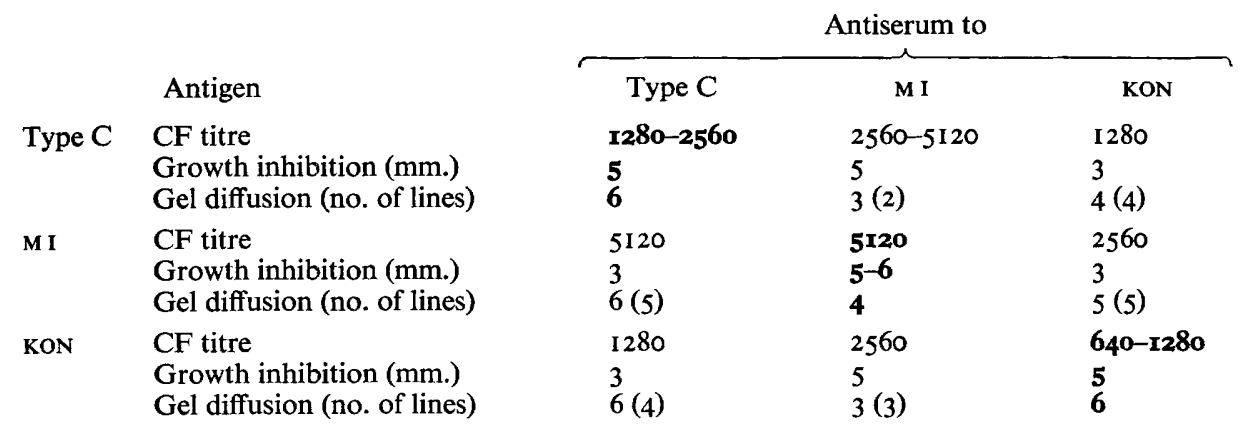

Since it could be argued that this line of type $\mathrm{C}$ had been cloned and so might have been selected from a mixed culture, another culture of type $\mathrm{C}$ was examined in Glasgow by a growth-inhibition technique (Clyde, I964), and by polyacrylamide gel electrophoresis, according to the method of Razin \& Rottem (1967). This was a lyophilized culture, received from Dr Tully at the 24th passage. In tests on part of the reconstituted culture removed directly from the original ampoule, its growth was inhibited by antisera to the Mycoplasma pulmonis strains ASH (PG 34), M 50, CHENG, NEGRONI, 880 and KON, but not by antiserum to the GDL strain of $M$. hyorhinis. In polyacrylamide gel electrophoresis, the cell proteins of type $\mathrm{C}$ gave a similar electrophoretic pattern to those of the prototype $M$. pulmonis strain ASH (PG 34).

Thus, the cultures of type $\mathrm{C}$ which we have examined appear to be strains of $\mathrm{Myco-}$ plasma pulmonis. Considering that cultures of type $\mathrm{C}$ received and examined independently in London and Glasgow were both closely related to M. pulmonis, it is unlikely that our results are due to accidental contamination with $M$. pulmonis, 
particularly since the growth-inhibition tests on type $\mathrm{C}$ before subcultivation gave the same result. Moreover, since Razin (1968) obtained evidence of a similarity between the cell proteins of another culture of type $\mathrm{C}$ and $M$. pulmonis, it is improbable that the relationship between type $\mathrm{C}$ and $M$. pulmonis is confined to the cultures we examined. Manchee \& Taylor-Robinson (1968) have also found a similarity between M. histotropicum and $M$. pulmonis in that colonies of both species adsorb rodent and guinea pig erythrocytes.

It is impossible, after nearly. 30 years, to determine what relation the cultures now known as type $\mathrm{C}$ bear to that originally isolated by Sabin. They differ in one respect; type $\mathrm{C}$ originally produced arthritis in mice after intravenous inoculation, but the culture recovered from Sabin's lyophilized ampoules was not mouse-pathogenic by the intraperitoneal, intravenous or intracerebral routes (Tully \& Ruchman, 1964). Nevertheless, current evidence suggests that type $\mathrm{C}$ belongs to the species Mycoplasma pulmonis and should not be classified as a separate species $M$. histotropicum. The extent to which strains differ within the species $M$. pulmonis is at present unknown, but the results of the gel-diffusion tests with type C, KON and M I, like those obtained by Fallon \& Jackson (1967), suggest that serological subtypes may exist.

K.A.F. is the Sir Maurice Bloch Research Fellow of the University of Glasgow. Work in the Glasgow laboratory was supported by a grant from the Secretary of State for Scotland on the recommendation of the Advisory Committee on Medical Research. We thank Dr J. G. Tully for his generosity in providing the cultures of type C.

\section{REFERENCES}

ClYdE, W. A. (1964). Mycoplasma species identification based upon growth inhibition by specific antisera. J. Immun. 92, 958.

EDWARD, D. G. ff. \& Freundt, E. A. (I956). The classification and nomenclature of organisms of the pleuropneumonia group. J. gen. Microbiol. 14, 197 .

Edward, D. G. ff. \& Freundt, E. A. (1969). Classification of the Mycoplasmatales. In The Mycoplasmatales and the L-phase of Bacteria. Ed. by L. Hayflick, p. 147. New York: Appleton-CenturyCrofts.

FALLON, R. J. \& JACKSON, D. K. (1967). The relationship between a rodent mycoplasma, Mycoplasma pulmonis, and certain mycoplasmas isolated from tissue cultures inoculated with material from patients with leukaemia. Lab. Anim. r, 55 .

Findlay, G. M., Klieneberger, E., MacCallum, F. O. \& Mackenzie, R. D. (1938). Rolling disease. New syndrome in mice associated with a pleuropneumonia-like organism. Lancet ii, 15 I I.

Klieneberger, E. (1940). The pleuropneumonia-like organisms: further comparative studies and a descriptive account of recently discovered types. J. Hyg., Camb. 40, 204.

LEMCKE, R. M. (196I). Association of PPLO infection and antibody response in rats and mice. J. Hyg., Camb. 59, 40I.

LEMCKE, R. M. (I964). The serological differentiation of Mycoplasma strains (pleuropneumonia-like organisms) from various sources. J. Hyg., Camb. 62, 199.

LEMCKE, R. M. (1965). A serological comparison of various species of Mycoplasma by an agar gel double-diffusion technique. J. gen. Microbiol. $\mathbf{3}^{8,9}$ r.

MANCHEE, R. J. \& TAYLOR-RoBINSON, D. (1968). Haemadsorption and haemagglutination by mycoplasmas. J. gen. Microbiol. 5o, 465 .

RAZIN, S. (1968). Mycoplasma taxonomy studied by electrophoresis of cell proteins. J. Bact. 96, 687.

RAZIN, S. \& RotTem, S. (I967). Identification of Mycoplasma and other micro-organisms by polyacrylamide-gel electrophoresis of cell proteins. J. Bact. 94, 1807. 
SABIN, A. B. (1938). Identification of the filtrable, transmissible neurolytic agent isolated from toxoplasma-infected tissue as a new pleuropneumonia-like microbe. Science, N.Y. 88, 575.

SABIN, A. B. (1939a). Experimental proliferative arthritis in mice produced by filtrable, pleuropneumonia-like micro-organisms. Science, N.Y. 89, 228.

SABIN, A. B. $(1939 b)$. Mice as carriers of pathogenic pleuropneumonia-like micro-organisms. Science, N.Y. 90, $\mathbf{1} 8$.

SABIN, A. B. (194I). The filtrable micro-organisms of the pleuropneumonia group. Bact. Rev. 5, I.

TulLY, J. G. (1965). Biochemical, morphological, and serological characterization of mycoplasma of murine origin. J. infect. Dis. 115, I7I.

Tully, J. G. \& Ruchman, L. (I964). Recovery, identification, and neurotoxicity of Sabin's Type A and $\mathrm{C}$ mouse mycoplasma (PPLO) from lyophilized cultures. Proc. Soc. exp. Biol. Med. r15, 554.

\section{Note added in proof}

Since the completion of this paper, two earlier subcultures of type C, at the $4^{\text {th }}$ and 7 th passages from Sabin's lyophilized culture, were obtained from $\operatorname{Dr}$ G. J. Tully. After 4 and 2 passages, respectively, the cultures were tested by the agar growthinhibition technique against antisera to the cloned line of type $\mathrm{C}$ and the $\mathrm{I} 7$ serologically distinct mycoplasmas cited in the text. Growth was inhibited only by antisera to type $\mathrm{C}$ and the Mycoplasma pulmonis strains KON and MI. Thus, cultures of type $\mathrm{C}$ passaged 8 and 9 times since recovery from Sabin's lyophilized material showed the same serological relationship to $M$. pulmonis as the later subcultures. 